Article

\title{
Joining Historic Cities to the Global World: Feasibility or Fantasy?
}

\author{
Ahmadreza Shirvani Dastgerdi * (1) and Giuseppe De Luca \\ Department of Architecture, School of Urban and Regional Planning, University of Florence, Via Micheli 2, \\ 50121 Florence, Italy; giuseppe.deluca@unifi.it \\ * Correspondence: ahmadreza.shirvanidastgerdi@unifi.it
}

Received: 31 March 2019; Accepted: 7 May 2019; Published: 9 May 2019

\begin{abstract}
Given the globalisation and free movement of capital and people, global cities compete with others not only as tourist destinations but also for the attraction of investors, skilled labour and well-educated citizens. In this research, the image of the historic city of Florence is investigated from the perspective of tourists and residents to assess the feasibility of joining historic cities to the global world. The sample size included 384 people who were randomly selected in the historic centre of Florence and answered the research questionnaire. The data was then analysed by descriptive statistics and logistic regression test. The findings show that although appropriate environmental qualities have made Florence highly successful in attracting tourists, what can promote the sustainability level of this historic city in the globalisation era is the organisation of urban planning in order to gain a part of global economic and human capital by creating the precise and unique image of the city.
\end{abstract}

Keywords: globalisation; historic city; city image

\section{Introduction}

Covering a broad variety of political, economic and cultural trends, the term "globalisation" has rapidly turned into one of the most commonly used words in contemporary political and scientific discussions. In general discourse, globalisation is considered a synonym for economic liberalisation, propagation and influence of political and cultural aspects of the Western world, development of information technologies and realisation of a united community where social conflicts are resolved [1]. Michael Pacione describes the emergence of global cities, deindustrialisation and weakening of old industrial cities as some of the most significant consequences of economic globalisation on the urban scale [2]. This role change is the result of the coordination of cities with new demands of the global economy, interpreted as an answer to globalisation by Abrahamson who believed that cities have headed in new directions for their revitalisation [3]. Today, global cities are in intense competition for the attraction of financial and human resources [4-6]. In this regard, the "global cities index" is applied to evaluate the level of globalisation of cities and also to compare them with each other. This index assesses the performance and development level of cities based on five dimensions, including business activities, human capital, cultural experience, information exchange and political engagement [7].

Europe is considered to be an appealing destination by tourists, which includes abundant historic landscapes and $47 \%$ of the world heritage sites [8]. Historic landscapes, large and small, include cities, towns and historic centres or quarters, together with their natural and human-made environments. In addition to historical value, these areas represent the value of traditional urban cultures [9-13]. In this regard, it is essential what the UNESCO "Recommendation on the Historic Urban Landscape" declares: "The historic urban landscape is the urban area understood as the result of a historic layering of cultural and natural values and attributes, extending beyond the notion of 'historic centre' or 'ensemble' to include the broader urban context and its geographical setting. This wider context includes notably the 
site's topography, geomorphology, hydrology and natural features, its built environment, both historic and contemporary, its infrastructures above and below ground, its open spaces and gardens, its land use patterns and spatial organization, perceptions and visual relationships, as well as all other elements of the urban structure. It also includes social and cultural practices and values, economic processes and the intangible dimensions of heritage as related to diversity and identity" [14]. In 2017, the EU's primary information suggested that a total of 28 member states accounted for $40 \%$ of the international arrivals with significant growth of $8 \%$ [15]. On the other hand, a report on the world's most prosperous cities in 2017 showed that only two European cities were ranked among the world's top ten global cities. Importantly, although Italy is at the top of the UNESCO World Heritage List with 54 inscribed properties [8], and therefore has a high potential for attracting international tourists and accordingly national economic growth [16], no Italian city is seen in the list of top 25 global cities [7]. In this respect, the question that arises is: Do historic cities include capacities or opportunities to capture a part of financial and human resources for which global cities compete and to be referred to as a "global city"? Alternatively, is their historic nature and structure a deterrent factor for joining the global flow and benefitting from its social and economic opportunities? The paper is, therefore, organised in the following steps: the first section contains a conceptual framework based on the city branding concept and its role in allocating resources to cities in the globalisation era. The second section develops a research design by selecting the historic centre of Florence as the case study. Then, descriptive statistics and logistic regression test applied for data analysis are in the third section. Finally, the spatial experiences of tourists and residents in the historic city of Florence are investigated and discussed to determine how social perception conceives the level of globalisation for Florence.

\section{Theoretical Framework}

Gentrification is a process of socio-spatial change in which middle-class residents move into working class areas, resulting in the displacement and exclusion of communities. In terms of mass tourism, the moving of residents provoked by tourists is called "tourism gentrification". As many rental apartments are being turned into accommodation facilities for visitors, tourism gentrification often leads to residential displacement, rent prices increasing and pressure on lower-income residents [17]. Tourism is often supposed to bring numerous economic advantages, as it creates jobs and positively affects the destination. However, mass tourism has also caused several economic troubles. Many destinations have to deal with seasonal fluctuations and therefore changes in demand. According to Bramwell [18], the tourism industry is therefore often concerned with having issues with seasonal unemployment as well as long working hours. Furthermore, much of the employment generated is often seasonal, unskilled and low-paid [19].

Given the globalisation and the free movement of capital, goods and people, cities compete with each other not only as tourist destinations [20] but also for the attraction of skilled labour, well-educated residents and investors through the city branding strategy [21]. City branding is concentrated on creating a distinctive and unique identity in the globalisation era, so that it can allocate more resources in competition with other cities and, thereby, improve the quality of citizens' lives [22]. In this sense, some studies have highlighted the significant role of branding in the sustainable development of cities [23-25]. It is essential to consider that city branding influences by a set of factors at various levels that play a crucial role in its success or failure [26].

Most public authorities and managers have noticed that there is a close link between the image of the city and its attractiveness as a place to visit, live, invest and study. The city image can be considered as one of the fundamental concerns both for city identity as well as city branding. It can be suitably interpreted at the intersection of city branding and city identity since the image is an essential part of both [27]. What matters in the first step of branding is a comprehensive understanding of the current city image, and it can be described from the perspective of residents, domestic and foreign. Some studies emphasise the role of city image as the significant determinant for visiting intention [26] and tourist destination marketers invest a high number of resources to create a favourable 
and desirable image to attract potential travellers to visit or revisit their destination [28]. Therefore, the participation of these three groups in expressing their views on the city is very constructive and useful in determining the urban planning policies. In this process, urban planning must balance the globalisation pressures and local needs and what complicates recognising and boosting city image is the wide range of stakeholders and general acceptability to city image.

Through identifying the city image, global cities endeavour to create a unique city brand in the public mind by showing a clear horizon of the city and thus minimise the uncertainty in investment and the concerns of human capital in selection $[29,30]$. Keep in mind that the city image has a mental nature and consists of a set of spatial experiences and attitudes towards a specific place for each person [25,31]. Therefore, the image can be noticed as one of the most important and most influential indicators which demonstrate people's feelings and tendencies towards the city [32,33]. Usually economic changes at regional, national and international levels, on the one hand, and political changes at organisational and national levels, on the other hand, have a significant impact on branding objectives in the long term [34]. Therefore, it is essential to recognise and boost the city image dynamically to create an impressive city brand [35]. In this sense, Lazzeretti \& Oliva [36] contributed to the debate of the economic transformation on cities discussing the case of Florence and its evolution from 'art city' to 'creative fashion city'. They attempted to understand if cultural and creative resources may contribute to the emergence of new trajectories or the renewal—or decline—of existing ones. Furthermore, they provided some insights of risks and opportunities related to rethinking the local economic transformation following a 'culture-led' and 'creativity-oriented' approach.

\section{Research Design}

\subsection{Case Study}

Florence is a historic city in Italy and the capital of Tuscany with nearly 382,000 residents [37]. It has been the capital of the Kingdom of Italy for six years from 1865 to 1871 [38]. Moreover, in the middle ages, Florence was one of the wealthiest cities as the business and financial centre of Europe, where the Italian Renaissance began to emerge later [39]. With an area of 505 hectares, the historic centre of Florence was inscribed on the UNESCO World Heritage List as a remarkable world heritage in 1982 [40]. Seven hundred years of cultural and artistic blooming are tangible today in the 14th-century Cathedral of Santa Maria del Fiore, the Church of Santa Croce, the Palazzo Vecchio, the Uffizi gallery and the Palazzo Pitti. The city's history is further evident in the artistic works of great masters such as Giotto, Brunelleschi, Botticelli and Michelangelo [41]. Florence's heritage consists not only of the stone and marble monuments which are admired by millions of visitors from all over the world but also of the cultural and literary works left by great artists, poets and writers as a legacy to humanity, works that have made Florence famous worldwide. According to the report of the municipality of Florence (Table 1), there was an increase of about $28 \%$ in the tourist presence in the Municipality of Florence from 2012 to 2017. The number of presences has always grown during these years, even by eight percent between 2016 and 2017 [42].

Table 1. The increase in tourist flow in recent years.

\begin{tabular}{cccc}
\hline Year & Total Presences & Extra-Hotel Presence & Hotel Presence \\
\hline 2012 & $7,983,799$ & $1,620,111$ & $6,363,688$ \\
\hline 2014 & $8,684,934$ & $1,902,964$ & $6,781,970$ \\
\hline 2015 & $9,215,038$ & $2,112,332$ & $7,102,706$ \\
\hline 2016 & $9,425,744$ & $2,384,107$ & $7,041,637$ \\
\hline 2017 & $10,202,876$ & $2,653,788$ & $7,549,088$ \\
\hline
\end{tabular}


The increase in presence in extra-hotel accommodation is robust in Table 1. It encompasses B\&Bs, farmhouses, holiday homes, hostels that rent through Airbnb by owners of buildings. The presence in these structures grew by $64 \%$ from 2012 to 2017. The data is certainly underestimated. Among the Italian cities most affected by the phenomenon are Rome with 29,519 announcements, Milan with 18,482, Florence with 11,341 and Venice with 8,025 announcements [43]. In 2018, those who rented accommodations through Airbnb stayed more than three nights and the average declines to 2.71 days if they prefer to stay in the hotel [44]. According to Federalberghi, 397,314 Italian accommodations were available on Airbnb in August 2018, with an exponential growth that shows no signs of stopping (174,528 more accommodations than in August 2016, equal to an increase of 78.34\%). Furthermore, there was a boom in domestic tourism, with an increase in overnight stays of Italians of $9.3 \%$, while for foreigners, growth was $2.4 \%$. Also, a growth for arrivals $(1.3 \%)$ and presences $(4.1 \%)$, with over $10,650,000$ overnight stays [45]. There are nearly 100,000 beds, 44,809 of which are in 562 hotels that have 20,463 rooms. Moreover, almost as many, there are 43,878 beds in 2,457 extra-hotel establishments [46].

\subsection{Method}

This study is descriptive-analytic research conducted by selecting the historic city of Florence as a case study. Using the Cochran formula and an error level of 5\%, a sample size of 384 people was chosen randomly in the historic centre of Florence. The information was collected by distributing a questionnaire in the historic centre of Florence to evaluate the globalisation level of the city based on the individuals' perception. The questionnaire was designed in the department of architecture at the University of Florence in November 2018. It consisted of 15 general questions, in addition to 5 designed questions for the tourists' group. Eighteen closed-ended plus two open-ended formed the style of the items. The validity of the questionnaire was controlled using related research in this field [47], and support of the panel of experts in the department. Then, the questionnaire was distributed in five most visited areas (Figure 1) at the historic centre of Florence during the first week of December 2018 (Table 2).

Table 2. Distribution of the questionnaires at the historic centre of Florence.

\begin{tabular}{cccc}
\hline Code & Area & Date & $\begin{array}{c}\text { Number of } \\
\text { Questionnaires }\end{array}$ \\
\hline A & Michelangelo's David (Academia Gallery) & 01.12 .18 & 76 \\
\hline B & Cathedral of Santa Maria Del Fiore & 03.12 .18 & 77 \\
\hline C & Basilica di Santa Croce & 05.12 .18 & 77 \\
\hline D & Piazzale Michelangelo & 06.12 .18 & 77 \\
\hline E & Ponte Vecchio & 07.12 .18 & 77 \\
\hline
\end{tabular}

Given that Nunnally (1978) determined a minimum acceptable reliability coefficient of 0.7 for the findings from the questionnaire [48], the reliability of data was calculated using the Cronbach's alpha, which equals 0.874 . In data analysis, the experience of participants and environmental qualities were initially studied using descriptive statistics. Then, the globalisation level of Florence was evaluated using a logistic regression test. This test is a statistical regression model for binary dependent variables, the occurrence of a random event in two possible situations. This model can be considered a generalised linear model that employs the logit function as a link function, and its error follows a polynomial distribution. 


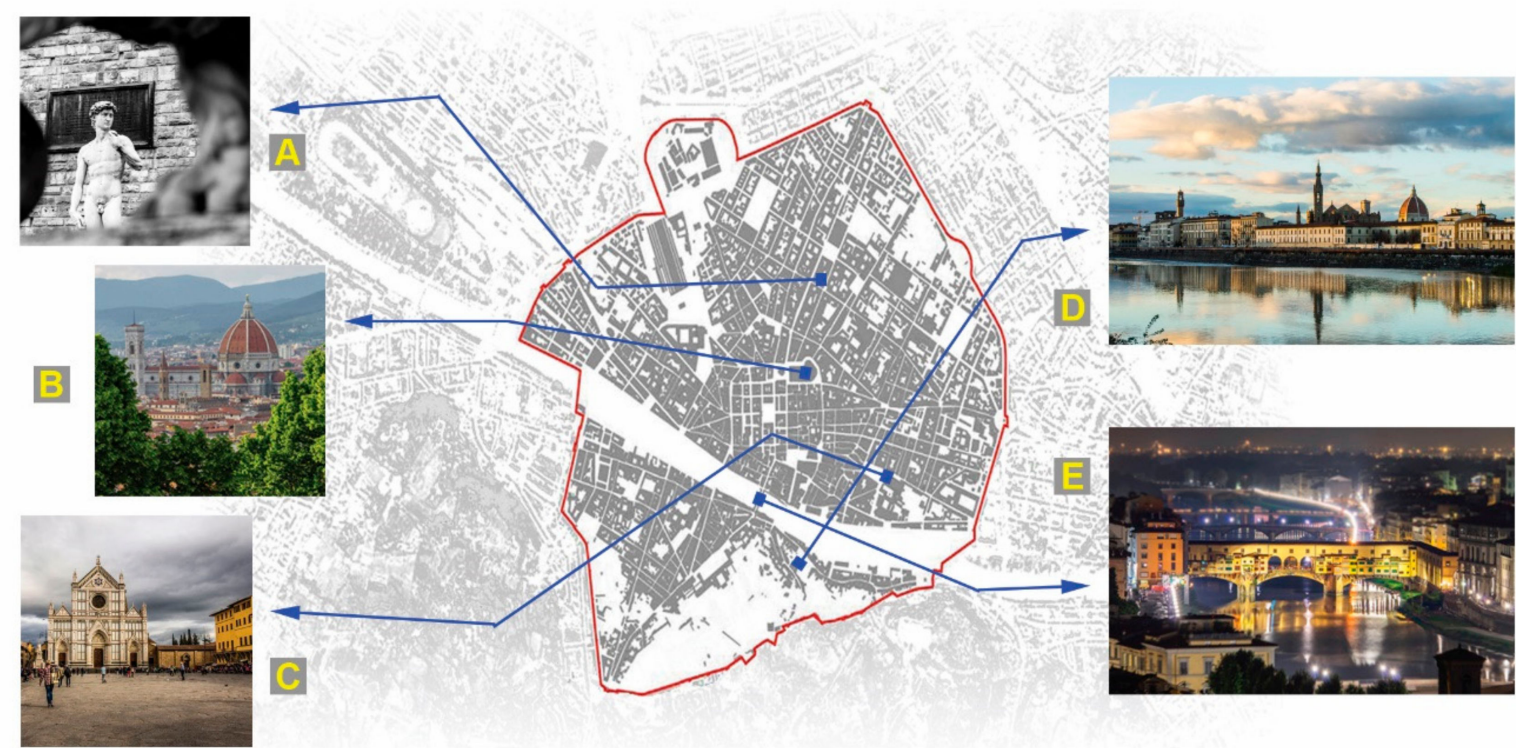

Figure 1. Places of distribution of questionnaires at the historic centre of Florence: A-Michelangelo's David (Academia Gallery), B-Cathedral of Santa Maria Del Fiore, C-Basilica di Santa Croce, D-Skyline of Florence, E-Ponte Vecchio [49].

\section{Results}

The initial investigation of the questionnaire (Figure 2) shows that tourists account for $54 \%$ (207 people) and Florentine residents account for 46\% (177 people) of the sample size. Most participants are from Europe, who account for $62 \%$ in total (residents cover $33.5 \%$ of this section).
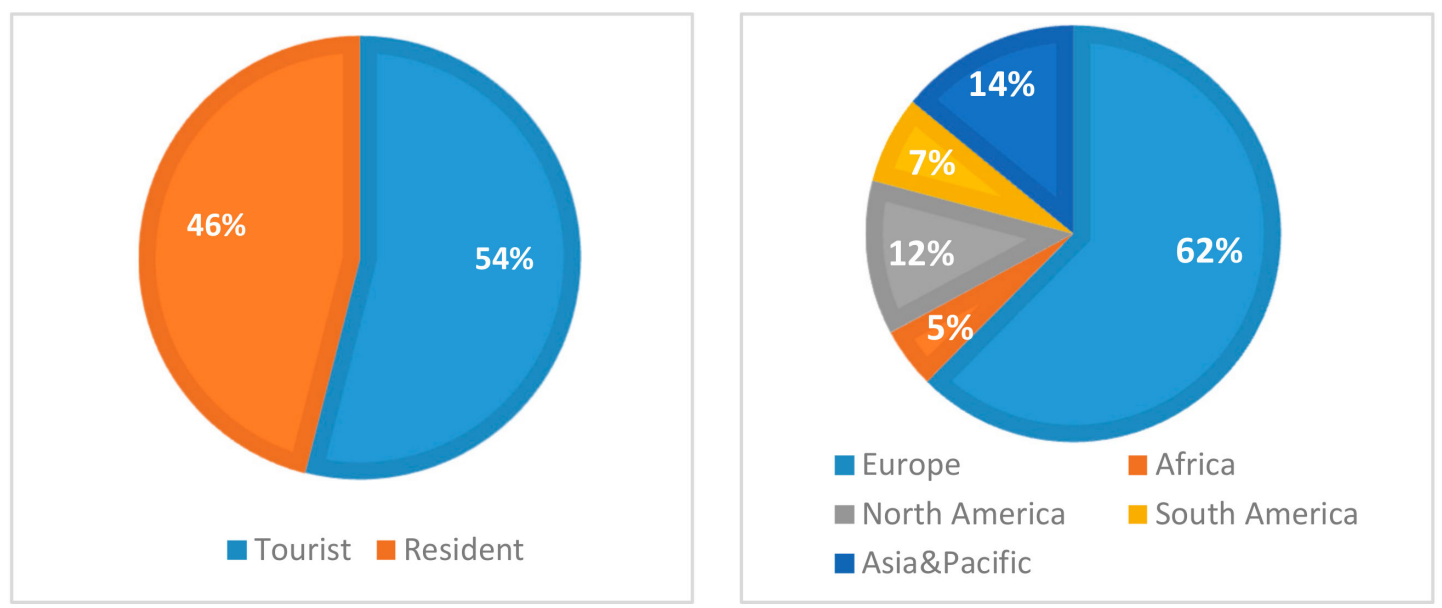

Figure 2. Left: frequencies for the type of residency; right: frequencies for each continent.

According to Figure 3, students make up $45 \%$, and the employed make up $30 \%$ of the sample size for the type of occupation, while $25 \%$ of the frequency accounts for people engaged in other activities. The sample size consists of 203 men and 181 women, and $45 \%$ are college graduates or have bachelor's degrees. 


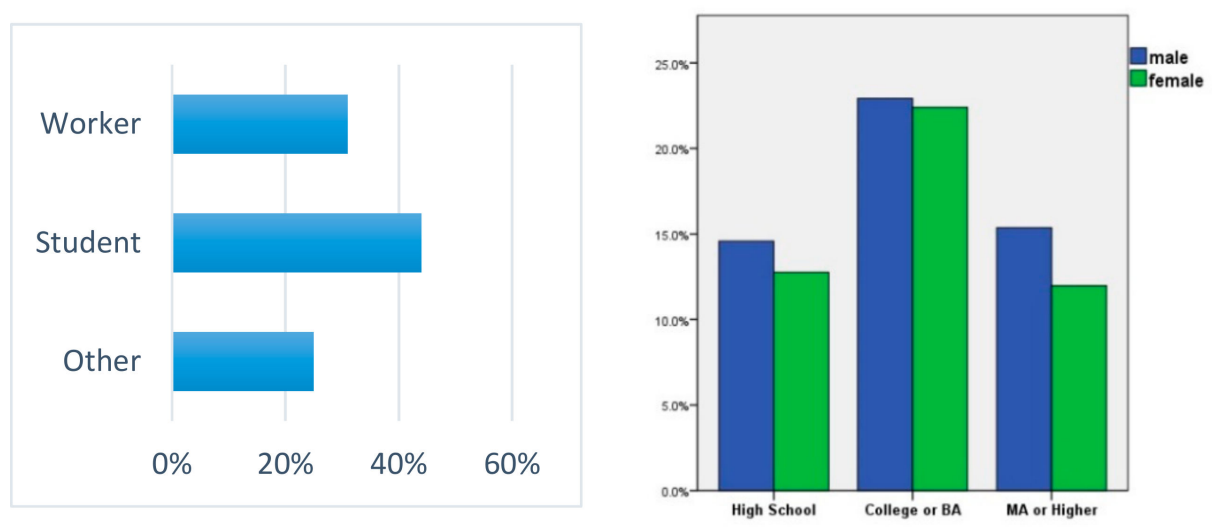

Figure 3. Left: frequencies for occupation type; right: frequencies for each gender and level of education.

Table 3 indicates that the participants of the 26-44 age group make up almost half of the frequency, while over-64-year-old participants have the least frequency percentage.

Table 3. Age groups in the sample size.

\begin{tabular}{cccc}
\hline \multirow{4}{*}{ Age groups } & Size & Frequency & Frequency Percentage \\
\cline { 2 - 4 } & $17-25$ & 122 & 31.8 \\
\cline { 2 - 4 } & $26-44$ & 180 & 46.9 \\
\cline { 2 - 4 } & $45-64$ & 60 & 15.6 \\
\cline { 2 - 4 } & $64+$ & 22 & 5.7 \\
\hline
\end{tabular}

The responses of tourists suggest that they stay in Florence for up to three days. The tourists claim that they get acquainted with Florence mostly by history (43.5\%) and then by their friends' recommendations (37.7\%), while the media with $12.6 \%$ and events with $2.4 \%$ have the least contributions to the introduction of Florence. A total of $42 \%$ of tourists agree that they know most places to visit in advance; $62 \%$ also agree that their presumed mental image of Florence is consistent with what they actually experienced. For the question of whether they want to visit Florence again or not, the tourists show their agreement with a stunning statistic, equal to $91.8 \%$ (Table 4 ).

Table 4. Descriptive statistics for tourists.

\begin{tabular}{cccc}
\hline Subject & Size & Frequency & Frequency Percentage \\
\hline \multirow{3}{*}{ Stay duration } & One day & 64 & 30.9 \\
\cline { 2 - 4 } & Three days & 119 & 57.5 \\
\cline { 2 - 4 } & One week & 19 & 9.2 \\
\cline { 2 - 4 } & More than a week & 5 & 2.4 \\
\cline { 2 - 4 } & Total & 207 & 100 \\
\hline \multirow{3}{*}{ Acquaintance } & Friend(s) & 78 & 37.7 \\
\cline { 2 - 4 } & Event(s) & 5 & 2.4 \\
\cline { 2 - 4 } & History & 90 & 43.5 \\
\cline { 2 - 4 } & Media & 26 & 12.6 \\
\cline { 2 - 4 } & Other & 8 & 3.9 \\
\cline { 2 - 3 } & Total & 207 & 100 \\
\hline
\end{tabular}


Table 4. Cont.

\begin{tabular}{|c|c|c|c|}
\hline Subject & Size & Frequency & Frequency Percentage \\
\hline \multirow{6}{*}{$\begin{array}{l}\text { Visit places based on previous } \\
\text { knowledge }\end{array}$} & Strongly agree & 42 & 20.3 \\
\hline & Agree & 87 & 42.0 \\
\hline & Neutral & 48 & 23.2 \\
\hline & Disagree & 28 & 13.5 \\
\hline & Strongly disagree & 2 & 1.0 \\
\hline & Total & 207 & 100 \\
\hline \multirow{6}{*}{$\begin{array}{l}\text { Consistency between previous } \\
\text { mental image and reality }\end{array}$} & Strongly agree & 32 & 15.5 \\
\hline & Agree & 129 & 62.3 \\
\hline & Neutral & 24 & 11.6 \\
\hline & Disagree & 22 & 10.6 \\
\hline & Strongly disagree & 0 & 0 \\
\hline & Total & 207 & 100 \\
\hline \multirow{3}{*}{ Tendency to revisit } & Yes & 190 & 91.8 \\
\hline & No & 17 & 8.2 \\
\hline & Total & 207 & 100 \\
\hline
\end{tabular}

A total of $69 \%$ of the residents of Florence state that they tend to remain citizens of Florence. As Table 5 shows, however, $70 \%$ of them discuss that it is not so easy to find affordable houses in this city.

Table 5. Descriptive statistics for residents.

\begin{tabular}{cccc}
\hline Subject & Size & Frequency & Frequency Percentage \\
\hline \multirow{3}{*}{ Residents' tendency to stay } & Yes & 119 & 69.0 \\
\cline { 2 - 4 } & No & 58 & 31.0 \\
\cline { 2 - 4 } & Total & 117 & 100 \\
\hline \multirow{3}{*}{ Finding affordable housing } & Not easy & 124 & 70.0 \\
\cline { 2 - 4 } & Easy & 53 & 30.0 \\
\cline { 2 - 4 } & Very Easy & 0 & 100 \\
\cline { 2 - 4 } & Total & 117 & \\
\hline
\end{tabular}

Florence has nearly 382,000 residents [37]. There are over 25,800 daily tourists and more than 76,200 commuters. Also, $46 \%$ of residents frequent the city centre: in one day, an average of over 137,700 Florentines go to the historical centre of the city [50]. For the beauty of the city, $63 \%$ of the participants describe Florence as a very attractive city. Moreover, $47.4 \%$ agree that they are highly satisfied with their spatial experience in Florence (Table 6). 
Table 6. Descriptive statistics for Florence city image.

\begin{tabular}{cccc}
\hline Subject & Size & Frequency & Frequency Percentage \\
\hline \multirow{3}{*}{ Beauty of city } & Attractive & 137 & 35.7 \\
\cline { 2 - 4 } & Very attractive & 242 & 63.0 \\
\cline { 2 - 4 } & Unattractive & 5 & 1.3 \\
\cline { 2 - 4 } & Total & 384 & 100 \\
\hline \multirow{3}{*}{ Spatial experience } & Not satisfactory & 25 & 6.5 \\
\cline { 2 - 4 } & Satisfactory & 177 & 46.1 \\
\cline { 2 - 4 } & Very satisfactory & 182 & 47.4 \\
\cline { 2 - 4 } & Total & 384 & 100 \\
\hline
\end{tabular}

The result of the Mann-Whitney $U$ test shows that there is no significant difference between the mean of the resident and tourist groups in terms of the beauty of the city (Table 7) and the spatial experience (Table 8).

Table 7. Descriptive statistics for Florence city image.

\begin{tabular}{cc}
\hline \multicolumn{2}{c}{ Test Statistics } \\
\hline \multicolumn{2}{c}{ Beauty of city } \\
\hline Mann-Whitney U & 18244.500 \\
\hline Wilcoxon W & 33997.500 \\
\hline $\mathrm{Z}$ & -0.082 \\
\hline Asymp. Sig. (two-tailed) & 0.935 \\
\hline a. Grouping Variable: Residents \& Tourists
\end{tabular}

Table 8. Descriptive statistics for Florence city image.

\begin{tabular}{cc}
\hline \multicolumn{2}{c}{ Test Statistics } \\
\hline & Spatial experience \\
\hline Mann-Whitney U & 14297.000 \\
\hline Wilcoxon W & 30050.000 \\
\hline Z & -0.062 \\
\hline Asymp. Sig. (two-tailed) & 0.761 \\
\hline
\end{tabular}

a. Grouping Variable: Residents \& Tourists

The questionnaire includes two open-ended questions. In the first question, the participants are asked to paint their mental image of Florence in less than a minute. The question shows the image of Florence in each person's mind "at the moment". The results of the analysis of the paintings suggest that the Florence Cathedral and its historical centre have the most frequency (Figure 4). 


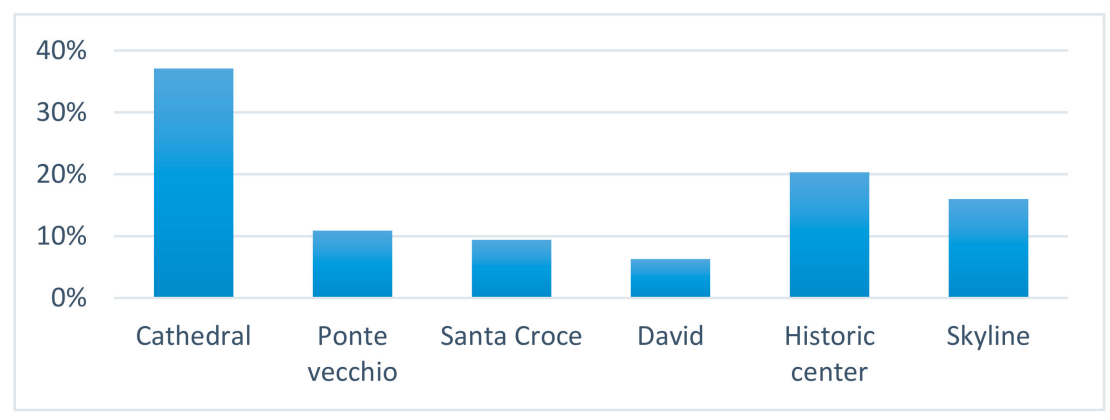

Figure 4. Participants' mental image of Florence based on the coding of paintings.

In the second question, they are asked to express the most important strengths of Florence in a maximum of three words. These answers can show the competitiveness and "future image of the city" from the attitude of the participants. The answers are categorised into general groups including art and architecture, history, pedestrian-orientation and food using content analysis (Figure 5).

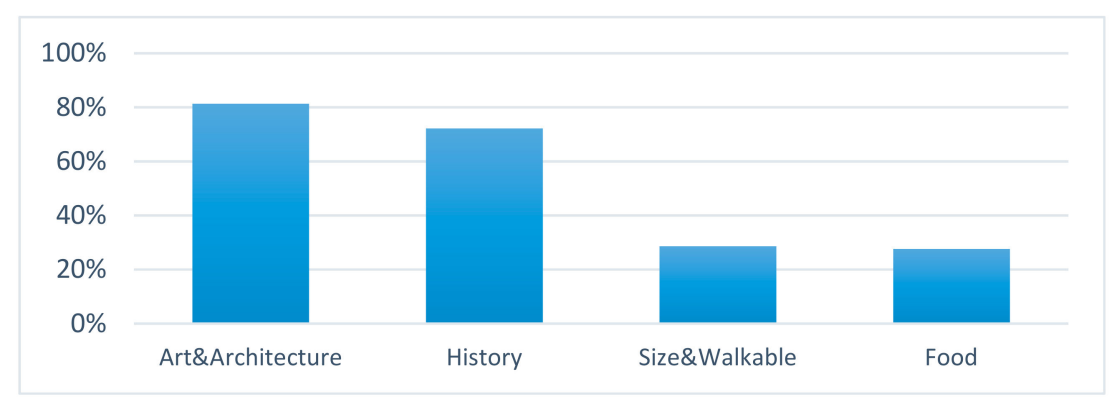

Figure 5. Most important potentials of Florence from the participants' attitude.

For the investigation of potentials, the participants are asked to give yes or no answers in order to define their mental image of Florence as "a favourable environment for global trade". In the logistic regression test, this parameter is considered as a dependent variable and its relationship with other variables of the questionnaire is analysed (i.e., favourability of social interactions, demand for citizenship, employment and affordable housing), hence $100 \%$ of the respondents (384 people) are engaged in the process. Table 4 shows that the variation of the dependent variable can be explained using four independent variables of the study with a reliability of $56.8 \%$ (Table 9).

Table 9. Classification table a,b.

\begin{tabular}{|c|c|c|c|c|c|}
\hline & \multirow{3}{*}{ Observed } & & \multicolumn{3}{|c|}{ Predicted } \\
\hline & & & \multicolumn{2}{|c|}{ Global } & \multirow{2}{*}{ Percentage Correct } \\
\hline & & & No & Yes & \\
\hline \multirow{3}{*}{ Step 0} & \multirow{2}{*}{ Global } & No & 218 & 0 & 100.0 \\
\hline & & Yes & 166 & 0 & 0.0 \\
\hline & \multicolumn{2}{|c|}{ Overall percentage } & & & 56.8 \\
\hline \multicolumn{6}{|c|}{ a. Constant is included in the model. } \\
\hline \multicolumn{6}{|c|}{ b. The cut value is 0.500} \\
\hline
\end{tabular}


Table 10 presents the overall evaluation of logistic regression model based on the results of the omnibus test. This test investigates how a model is explanatory and effective. Given the significance level of the model, the model processing is acceptable and significant at an error level of less than $5 \%$.

Table 10. Omnibus tests of model coefficients.

\begin{tabular}{ccccc}
\hline \multirow{3}{*}{ Step 1 } & & Chi-Square & Df & Sig. \\
\cline { 2 - 5 } & Step & 46.246 & 4 & 0.000 \\
\cline { 2 - 5 } & Block & 46.246 & 4 & 0.000 \\
\hline
\end{tabular}

Table 11 presents the results of three statistics of the logarithm, likelihood and Cox-Snell R-square. These coefficients are approximations of coefficients of determination in linear regression, used in the logistic regression.

Table 11. Model summary.

\begin{tabular}{cccc}
\hline Step & $\mathbf{- 2}$ Log Likelihood & Cox \& Snell R-Square & Nagelkerke R-Square \\
\hline 1 & $479.027 a$ & 0.113 & 0.152 \\
\hline
\end{tabular}

a. Estimation terminated at iteration number 4 because parameter estimates changed by less than 0.001 .

As observed, the values of Cox and Snell R-square and Nagelkerke R-square are determined to be $11.3 \%$ and $15.2 \%$, respectively, indicating that the independent variables can explain $15.2 \%$ of the variations of the dependent variable. In Table 12, the effect of independent variables on the dependent variable is assessed.

Table 12. Variables in the equation.

\begin{tabular}{|c|c|c|c|c|c|c|c|c|c|}
\hline & & \multirow{2}{*}{ B } & \multirow{2}{*}{ S.E. } & \multirow{2}{*}{ Wald } & \multirow{2}{*}{ Df } & \multirow{2}{*}{ Sig. } & \multirow{2}{*}{$\operatorname{Exp}(B)$} & \multicolumn{2}{|c|}{ 95\% C.I.for EXP(B) } \\
\hline & & & & & & & & Lower & Upper \\
\hline \multirow{5}{*}{ Step 1a } & Interactions & -0.431 & 0.123 & 12.335 & 1 & 0.000 & 0.650 & 0.511 & 0.827 \\
\hline & Citizenship & 0.843 & 0.226 & 13.919 & 1 & 0.000 & 2.323 & 1.492 & 3.616 \\
\hline & Employment & 0.580 & 0.188 & 9.523 & 1 & 0.002 & 1.786 & 1.236 & 2.581 \\
\hline & Housing & 0.370 & 0.189 & 3.835 & 1 & 0.049 & 1.448 & 1.000 & 2.097 \\
\hline & Constant & -1.509 & 0.623 & 5.863 & 1 & 0.015 & 0.221 & & \\
\hline
\end{tabular}

Table 12 suggests that the favourability of social interactions with $43.1 \%$, demand for citizenship with $84.3 \%$, employment with $58 \%$ and affordable housing with $37 \%$ have a significant effect on the variable of the favourable environment for global trade.

\section{Discussion}

The rise in the number of tourists is usually considered to be a sort of indicator of the resolution of a specific policy, and this could not necessarily be true. The growth in the number of visitors cannot be considered to be positive in use, without taking into account the quality of the tourist experience and the visitor yield [51]. In this study, the respondents' answers show that the historic city of Florence has been able to provide visitors with its historical and cultural values at a high quality. Most tourists who participated in the study highly tend to revisit Florence in the future, in addition to describing their trip experience in Florence as "very satisfied". This suggests that the urban management of 
Florence has succeeded in "attraction of tourists" as a consequence of globalisation and benefitting from its economic potential at an ideal level. On the other hand, the residents refer to job opportunities from two views. Some say that finding a job according to their expertise is "almost impossible" in the city. Others deem job opportunities dependent on tourism activities and maintain that it is "difficult" to find a stable job in this regard, referring to changes in the volume of tourism in different seasons. It seems that although tourism activities are defined as an advantage of economic development in global cities, these activities become central to the economy of historic cities and deteriorate many other economic opportunities which could be created by the promotion of globalisation level and the use of experts and investors in these cities. In other words, tourism activities dominate and organise other economic activities. This seems more considerable in this study when it is found that $70 \%$ of the participant residents describe finding affordable housing difficult in Florence. If this is compared with the residents' view on job opportunities, it is deduced that this orientation has not succeeded in satisfying the citizens. The "tourist-orientation" still organises spatial structures and activities in historic cities, while urban planners have exceeded the level in global cities, causing cities to compete with each other to attract investors, experts and educated people. In other words, the attraction of tourists is a set of factors that contribute to the formation or determination of the status of a global city.

The media and events play a vital role in the competition of global cities to attract financial and human resources [52,53]. However, these tools are neglected in explaining a "unique" and "certain" city image of the city for Florence. The responses show that most tourists get acquainted with Florence through "the history" and the least through the media and events. This result highlights that the management plan has not been successful in promoting the city image as it states "in the realms of the increase of soft power, the organisation of international events in the Historic Centre is a significant way of enhancing the image of Florence in the world" [41].

To understand the "instant image" in the participants' minds in this study, they are asked to draw Florence within a minute. These paintings include various buildings of the city, which featured historical aspects. Aimed at determining the "future image" of the city, another open-ended question also shows that only architectural and historical features still shape the participants' mentality. It is found that the tourism-orientation and ignorance of other globalisation potentials cause the "past" to form the horizon and future of this city in the visitors' minds. This orientation happens while tourism in Florence is not merely cultural, but also linked to pleasure and leisure [41]. It should be noted that "future image of a historic city" never means the denial of its history and cultural characteristics. However, it is an attempt to achieve a common goal in the competition of cities, which is accepted by most citizens. This goal is accompanied by changes in the role of a historic city as a place merely for recreation and seeks a unique strategy to keep its sustainability in the competition of cities by attracting specific financial and human resources. This strategy is planned and developed based on urban horizons, distinctive features and globalisation level of historic cities. For example, in response to the question "I would like to be or remain a resident in Florence? (If no, why?)", some answers referred to the "brand" or the "logo" of other destinations. In this sense, it suggests how some specific destinations already have succeeded in ensuring the quality of place and wellbeing of the citizen through a certain and acceptable city brand.

The results of logistic regression analysis aimed at evaluating the favourability of Florence as an environment for global trade show that independent variables (e.g., favourability of social interactions, demand for citizenship, employment and affordable housing) can explain $15.2 \%$ of global trade changes in Florence from the view of participants. The results of this test indicate that the demand for citizenship in Florence has the most significant effect on this model. This can be considered from two perspectives: first, the formation of a "good mental image" of the place experienced by residents of Florence; and second, the effects of this mental image on foreign tourists as a result of social interactions. Hence, the favourability of social interactions is another factor affecting Florence as a global city. As shown by descriptive statistics in this study, the environmental quality of Florence and its highly satisfactory spatial experience may be a critical factor in tourists' tendency to revisit the city. Therefore, it is 
concluded that historical nature and spatial form of Florence play an influential role in the global definition of this city and are not deterrents in this regard. However, the findings demonstrate that this city is defined as a place for recreation and leisure in mental images and does not go beyond that.

\section{Conclusions}

Aimed at evaluating the feasibility of joining historic cities to the global world, this study investigates the people's mental image of Florence as a global city. The results of this study indicate that what limits historic cities from joining the global world is not their historic structure and nature, but how opportunities emerge. Although tourist presence can contribute to the sustainable development of economic and social conditions for the residents, it can also provoke the rise of environmental pressures. If the adverse consequences exceed the advantages, historic centres suffer from the alteration of their environmental, economic and social structure. Also, the tourism-orientation and organisation of activities based on tourism cause the opportunities defined by changes in the volume of tourists to become unsustainable and mostly require no specialised expertise. In other words, tourism plays a vital role in the economy of historic cities, while its job opportunities remain limited to recreation and leisure. On the other hand, global cities go far beyond to ensure sustainability in the competition of cities and compete to attract experts, investors and educated people. What urban planning needs in historic cities to ensure its sustainability and survival is identifying the city image and creating a unique city brand which enhances the citizens' quality of life and the sense of belonging in the globalisation era. Since communities change over time, the city image should be continually reviewed and strengthened. In the creation of an impressive city brand, urban planning requires paying special attention to activities that boost the image of a competitive city in terms of human health, quality of life, job creation, building public spaces and environmental innovations. Besides, proper identification of stakeholders and developing a sufficient participatory and communication approach guarantees the acceptability of city brand. Hence, it is essential to move towards a way that reduces the dependence of the economy of cities on tourism activities and plans and substitutes other levels of services and activities related to the world economy in these cities. This critical issue mainly requires a specific and unique definition of horizons of the historic city, and it should be noted that the emergence and sustainability of a thriving city brand are not achieved if all the stakeholders endorse that. This attitude towards the planning of historic cities can be conceived as a new paradigm that depicts the economic and social sustainability of historic cities within a framework beyond tourism-orientation during an era when cities intensely compete to attract resources in the world. Indeed, this research was carried out in only one period of the year; however, the selection of the sample is scientifically significant. The actual limit was related to the type of tourist flows, which can vary from period to period and this can somewhat affect the expressed opinions. Although the chosen period is one of the most standard ones, it may be useful to repeat the operation next year in a different period. This action would allow a comparison.

Author Contributions: A.S.D. and G.D.L. equally contributed to the writing of this paper. A.S.D. did the literature review, suggested research methodology, did field research and created the figures and table. G.D.L. Promoted the research methodology, supervised the research and proofread the manuscript.

Funding: This work was supported by a research grant, grant number of 1523274135, from the Ministry of Foreign Affairs and International Cooperation (Ministero degli affari esteri e della cooperazione internazionale).

Conflicts of Interest: The authors declare no conflict of interest.

\section{References}

1. Globalization Stanford Encyclopedia of Philosophy. Available online: https://plato.stanford.edu/entries/ globalization/ (accessed on 28 November 2018).

2. $\quad$ Pacione, M. Urban Geography: A Global Perspective; Routledge: London, UK, 2005; ISBN 9788578110796.

3. Abrahamson, M. Global Cities; Oxford University Press: New York, NY, USA, 2004. 
4. Cleave, E.; Arku, G.; Sadler, R.; Gilliland, J. The role of place branding in local and regional economic development: Bridging the gap between policy and practicality. Reg. Stud. Reg. Sci. 2016, 3, 207-228. [CrossRef]

5. Petrea, R.; Petrea, D.; Olău, P.E.; Filimon, L. Place branding as efficient management tool for local government. Transylv. Rev. Adm. Sci. 2013, 9, 124-140.

6. Rizzi, P. From strategic planning to city branding: Some empirical evidence in Italy. J. Tour. Cult. Herit. 2010, 8, 39-49. [CrossRef]

7. Kearney, A.T. Global Cities 2017. Leaders in a World of Disruptive Innovation. Last Modif. 2017. Available online: https:/www.atkearney.com/documents/10192/12610750/Global+Cities+2017+-+Leaders+in+a+World+ of+Disruptive+Innovation.pdf/c00b71dd-18ab-4d6b-8ae6-526e380d6cc4 (accessed on 9 May 2019).

8. UNESCO World Heritage List Statistics. Available online: https://whc.unesco.org/en/list/stat (accessed on 21 January 2019).

9. Icomos, R. Charter on the Conservation of Historic Towns and Urban Areas: 'The Washington Charter'. ICOMOS. 1987 Aug 10. Available online: https://www.icomos.org/charters/towns_e.pdf (accessed on 9 May 2019).

10. Shirvani Dastgerdi, A.; De Luca, G. Specifying the significance of historic sites in heritage planning. Conserv. Sci. Cult. Herit. 2018, 18, 29-39. [CrossRef]

11. Shirvani Dastgerdi, A.; De Luca, G. Heritage planning process: An outlook on maintenance management. In Proceedings of the XXII Conferenza Nazionale SIU; Planum: Matera; Planum: Matera, Italy; Bari, Italy, 2019.

12. Seirafian Baboldashti, M.; Tabaeian, S.M.; Shirvani Dastgerdi, A. The Influence of natural ideas in promoting Genius Loci (case study of Sheikh Lotfollah Mosque in Isfahan). J. Islam. Archit. 2018, 5, 53-60. [CrossRef]

13. Shirvani Dastgerdi, A.; De Luca, G. Religious differences and radical special transformations in historic urban landscapes. Conserv. Sci. Cult. Herit. 19. (in press).

14. UNESCO. Recommendation on the Historic Urban Landscape; UNESCO: Paris, France, 2011.

15. UNWTO. European Union Short-Term Tourism Trends; UNWTO: Madrid, Spain, 2018; Volume 2.

16. Shirvani Dastgerdi, A.; De Luca, G. The riddles of historic urban quarters inscription on the UNESCO world heritage list. Int. J. Archit. Res. ArchNet IJAR 2018, 12, 152-163. [CrossRef]

17. Cócola-Gant, A. Tourism and commercial gentrification. In Proceedings of the The Ideal City. Between Myth and Reality, Urbino, Italy, 27-29 August 2015.

18. Bramwell, B. Coastal Mass Tourism: Diversification and Sustainable Development in Southern Europe; Channel View Publications: Bristol, UK, 2004; Volume 12.

19. Rátz, T. Residents' perceptions of the socio-cultural impacts of tourism at Lake Balaton, Hungary. In Tourism and Sustainable Community Development; Routledge: Abingdon-on-Thames, UK, 2002; pp. 54-65.

20. Hanna, S.; Rowley, J. Towards a strategic place brand-management model. J. Mark. Manag. 2011, 27, 458-476. [CrossRef]

21. Zenker, S.; Martin, N. Measuring success in place marketing and branding. Place Brand. Public Dipl. 2011, 7, 32-41. [CrossRef]

22. Popescu, G.V. From local to global with city branding. Ecoforum J. 2017, 6. Available online: http://ecoforumjournal. ro/index.php/eco/article/viewFile/515/351. (accessed on 9 May 2019).

23. Dinnie, K. Nation Branding: Concepts, Issues, Practice; Routledge: Abingdon-on-Thames, UK, 2015.

24. Maheshwari, V.; Vandewalle, I.; Bamber, D. Place branding's role in sustainable development. J. Place Manag. Dev. 2011, 4, 198-213. [CrossRef]

25. Rehan, R.M. Urban branding as an effective sustainability tool in urban development. HBRC J. 2014, 10, 222-230. [CrossRef]

26. Shirvani Dastgerdi, A.; De Luca, G. Boosting city image for creation of a certain city brand. Geogr. Pannonica 2019, 23, 23-31. [CrossRef]

27. Riza, M.; Doratli, N.; Fasli, M. City branding and identity. Procedia Soc. Behav. Sci. 2012, 35, $293-300$. [CrossRef]

28. Martins, M. The tourist imagery, the destination image and the brand image. J. Tour. Hosp. Manag. 2015, 3, 1-14. [CrossRef]

29. Kavaratzis, M.; Ashworth, G. City branding: An effective assertion of identity or a transitory marketing trick? Tijdschrift voor Economische en Sociale Geografie 2005, 96, 506-514. [CrossRef] 
30. Ashworth, G.J. The instruments of place branding: How is it done? Eur. Spat. Res. Policy 2009, 16, 9-22. [CrossRef]

31. Herget, J.; Petrů, Z.; Abrhám, J. City branding and its economic impacts on tourism. Econ. Sociol. 2015, 8, 119. [CrossRef] [PubMed]

32. Rukayah, R.S.; Wibowo, A.A.; Wahyuningrum, S.H. City Branding in Pekalongan, Central Java. Asian J. Behav. Stud. 2016, 1, 13-22. [CrossRef]

33. Anholt, S. Places: Identity, Image and Reputation; Springer: London, UK, 2016; ISBN 9780230251281.

34. Kulibanova, V.V.; Teor, T.R. Identifying key stakeholder groups for implementing a place branding policy in Saint Petersburg. Balt. Reg. 2017, 9, 99-115. [CrossRef]

35. Shirvani Dastgerdi, A.; De Luca, G. Creation of impressive city brand in the age of cities. City Territ. Archit.. (in revision).

36. Lazzeretti, L.; Oliva, S. Rethinking city transformation: Florence from art city to creative fashion city. Eur. Plan. Stud. 2018, 26, 1856-1873. [CrossRef]

37. ISTAT Istituto Nazionale di Statistica. Available online: http://demo.istat.it/ (accessed on 12 December 2018).

38. Poettinger, M.; Roggi, P. Florence: Capital of the Kingdom of Italy, 1865-1871; Bloomsbury Publishing: London, UK, 2017.

39. Fanelli, G. Firenze; Roma Bari: Laterza, Italy, 2002; ISBN 88-420-1662-4.

40. World Heritage Centre. Historic Centre of Florence. Available online: https://whc.unesco.org/en/list/174 (accessed on 12 December 2018).

41. UNESCO Office of the Municipality of Florence. The Management Plan of the Historic Centre of Florence; UNESCO Office of the Municipality of Florence: Florence, Italy, 2016.

42. Municipality of Florence Statistica del Turismo. Available online: http://www.cittametropolitana.fi.it/turismo/ statistica-del-turismo/ (accessed on 4 May 2019).

43. Federalberghi Federalberghi Firenze: "Città Dormificio. Posti Letto Aumentano più dei Flussi Turistici". Available online: https:/www.gonews.it/2018/09/25/federalberghi-firenze-citta-dormificio-postiletto-aumentano-piu-dei-flussi-turistici/ (accessed on 4 May 2019).

44. IRPET. Rapporto Sul Turismo in Toscana la Congiuntura 2017; IRPET: Florence, Italy, 2018.

45. Regione Toscana Movimento Turisti Nelle Strutture Ricettive e Struttura Dell'offerta: Dati 2018. Available online: http://www.regione.toscana.it/statistiche/dati-statistici/turismo/-/asset_publisher/ 6vQYNI057gs2/content/movimento-turisti-nelle-strutture-ricettive-e-struttura-dell-offerta-dati-2018; jsessionid=FA8997089B227D17D7563DA20C1ED8F9.web-rt-as01-p2? redirect=htt (accessed on 4 May 2018).

46. A Cura Della UO Statistica e Studi Della Camera di Commercio di Firenze. Il Cruscotto Degli Indicatori Economici Dell'area Metropolitana Fiorentina Camera di Commercio: Firenze, Italy 2019. Available online: http://www.fi.camcom.gov.it/sites/default/files/uploads/Studi_Informazione_Economica/cruscotto_ FI_gen_2019.pdf (accessed on 9 May 2019).

47. Loda, M. Analizzare l'immagine dei luoghi: Firenze visitata e vissuta. La ricerca empirica nel lavoro del geografo 2010, 41, 4-8.

48. Nunnally, J. Psychometric Methods; McGraw-Hill: New York, NY, USA, 1978.

49. Bandini, N. Firenze città d'arte: Le immagini del Centro Storico Patrimonio Mondiale. Available online: http://www.firenzepatrimoniomondiale.it/gallery/ (accessed on 20 April 2019).

50. Redazione IL Comune di Firenze e Vodafone Analizzano i Mobile Analytics per Conoscere Meglio le Presenze in Città. Available online: https:/www.cittadiniditwitter.it/news/il-comune-di-firenze-e-vodafoneanalizzano-i-mobile-analytics-per-conoscere-meglio-le-presenze-in-citta/ (accessed on 4 May 2019).

51. Montanari, A.; Staniscia, B. Rome: A difficult path between tourist pressure and sustainable development. Rivista di Scienze del Turismo 2010, 1, 301-316.

52. Aysu, G.Ç. Managing the image of cities in the "global village" city branding as an opportunity against globalization. Archnet-IJAR Int. J. Archit. Res. 2013, 7, 258-268.

53. Grichting, A. Scales of flows: Qatar and the urban legacies of mega events. Archnet IJAR Int. J. Archit. Res. 2013, 7, 173-191.

(C) 2019 by the authors. Licensee MDPI, Basel, Switzerland. This article is an open access article distributed under the terms and conditions of the Creative Commons Attribution (CC BY) license (http://creativecommons.org/licenses/by/4.0/). 